\title{
Is there a link between TNF gene expression and cognitive deficits in depression?
}

\author{
Kinga Bobińska', Elżbieta Gałecka², Janusz Szemraj³, Piotr Gałecki and Monika Talarowska1凶 \\ 'Department of Adult Psychiatry, Medical University of Lodz, Łódź, Poland; 2Department of Pulmonology and Allergology, Medical University of \\ Lodz, Łódź, Poland; '3Department of Medical Biochemistry, Medical University of Lodz, Łódź, Poland
}

\begin{abstract}
Neuroinflammation is a known factor in the pathogenesis of recurrent depressive disorders. Depression is accompanied by activated immune-inflammatory pathways including increased levels of TNFa, sTNFR1and sTNFR2. The purpose of this study was to analyse the TNF- $a$, TNFRSF1A and TNFRSF1B genes on both MRNA and protein levels in patients with rDD, and to investigate the relationship between TNF- $a, T N F R S F 1 A$ and TNFRSF1B gene expression and cognitive performance. The study comprised 158 subjects: patients with recurrent depressive disorder $(n=89)$ and healthy subjects $(n=69)$. Cognitive function assessment was based on: Trail Making Test, The Stroop Test, Verbal Fluency Test and Auditory Verbal Learning Test. Both mRNA and protein expression levels of all genes were significantly higher in rDD subjects when compared to healthy controls. No statistically significant correlations were observed between the analysed variables in both the rDD group and the HS test group. The only exception was noticed in the HS test group, where increased expression of TNFRSF1A and TNFRSF1B gene negatively affected the performance of the AVLT test. However, statistically significant correlations between TNF, TNFRSF1A, TNFRSF1B mRNA gene expression levels and all the neuropsychological tests used in the survey for the entire group were observed. Conclusions: 1.The results of our study show increased expression of the TNF, TNFRSF1A and TNFRSF1B genes on both $\mathrm{MRNA}$ and protein levels in depression. 2. Elevated expression of TNF- $a, T N F R S F 1 A$ and TNFRSF1B negatively correlates with cognitive efficiency: working memory, executive functions, attention, auditory-verbal memory, effectiveness of learning processes and verbal fluency.
\end{abstract}

Key words: depressive disorder, TNF-a, TNFRSF1A, TNFRSF1B, cognitive impairment

Received: 22 February, 2016; revised: 19 September, 2016; accepted: 16 November, 2016; available on-line: 16 December, 2016

\footnotetext{
e-mail: talarowskamonika@wp.pl

Abbreviations: AD, Alzheimer's disease; AVLT, the Auditory Verbal Learning Test: CFS, chronic fatigue syndrome; CNS, Central Nervous System; HDRS, Hamilton Depression Rating Scale; HS, healthy subjects; IDO, indolamine-2,3-dioxygenase; IL-6, interleukin 6; L-1 $\beta$, interleukin 1 beta; M, mean; MMSE, Mini-Mental State Examination; $O C D$, obsessive-compulsive disorder; $r D D$, recurrent depressive disorder; SD, standard deviation; TMT, the Trail Making Test (TMT); TNFR1, tumour necrosis factor receptor 1; TNFRSF1A, tumour necrosis factor receptor superfamily member 1A; TNFRSF1B, tumour necrosis factor receptor superfamily member $1 \mathrm{~B}$; TNF-a, tumour necrosis factor alpha; TNRF2, tumour necrosis factor receptor 2 ; VFT, the Verbal Fluency Test
}

\section{INTRODUCTION}

Neuroinflammation is a known factor in the pathogenesis of recurrent depressive disorder (rDD) (Singhal et al., 2014). Depression is an immune-inflammatory illness characterized by systemic and neuroinflammatory responses and by oxidative and nitrosative stress and neuroprogression (Maes et al., 1990-1991; Moylan et al., 2013, Moylan et al., 2014). A number of studies have shown increased expression of pro-inflammatory cytokines, such as TNF- $\alpha$ (tumour necrosis factor alpha), IL-1 $\beta$ (interleukin 1 beta), and IL-6 (interleukin 6), in the brain of patients with depression leading to neuroinflammation (Dowlati et al., 2010; Hannestad et al., 2011). On the other hand, there is accumulating evidence of alterations in the peripheral immune system with increased circulating levels of pro-inflammatory cytokines in depressive disorders (Anisman, 2009). The first studies indicating an increased level of TNF- $\alpha$ in patients with depression were published as early as in 2000 (Lanquillon et al., 2000; Milikova et al., 2001). Moreover, increased levels of $\mathrm{TNF}-\alpha$ in plasma are linked with the fact that treatment is resistant to the use of conventional antidepressants (O'Brien et al., 2007). It has also been demonstrated that TNF- $\alpha$ antagonism improves treatment of resistant depression in a subgroup of patients with high baseline inflammatory biomarkers (Rison et al., 2013).

Cytokines are small proteins, which are produced by a variety of immune cells (lymphocytes, macrophages, natural killer cells etc.). They are important for cell signalling when the immune system is mounting inflammatory responses to infection and cell damage (Sudheimer et al., 2014). The circulating proinflammatory cytokines such as $\mathrm{TNF}-\alpha$ are thought to promote the depressive disorder by affecting the functions of the Central Nervous System (CNS) in multiple ways (Mikova et al., 2001; Dantzer et al., 2008). TNF- $\alpha$ seems to contribute to the pathophysiology of depression by activating monoamine reuptake, stimulating the hypothalamic-pituitaryadrenocortical axis (HPA) and decreasing production of serotonin due to the increased activity of indolamine-2,3dioxygenase (IDO) (Lichtblau et al., 2013). Moreover, cytokines like TNF- $\alpha$ link the non-specific immune system to the hypothalamo-pituitary-adrenocortical (HPA) axis. $\mathrm{TNF}-\alpha$ and its soluble receptors p55 and p75, which are released during infection and inflammation, activate the HPA system at the hypothalamic, pituitary and adrenal level resulting in the release of cortisol, being the most significant negative feedback signal preventing an overshoot of the ongoing host defense (Silverman et al., 2005). A chronically activated HPA axis - as occurring during chronic stress - leads to defective responses of the immune system to inflammatory challenges (Bese- 
dovsky \& del Reay, 2000). Exogenous TNF- $\alpha$ administration causes the release of CRH (corticotropin-releasing hormone), ACTH (adrenocorticotropic hormone) and cortisol (Michie et al., 1988).

The action of TNF- $\alpha$ depends on the stimulation of specific receptors: TNFR1 (tumour necrosis factor receptor $1 /$ tumour necrosis factor receptor superfamily member 1A, TNFRSF1A) and TNFR2 (tumour necrosis factor receptor 2 /tumour necrosis factor receptor superfamily member 1B, TNFRSF1B) (Lichtblau et al., 2013).

Besides the well-established mood changes, it has been recently recognised that a generalised cognitive deficit is at the core of depression (Talarowska et al., 2014). Many studies also report that elevated pro-inflammatory cytokines negatively affect hippocampal structure and cognitive functioning (Sudheimer et al., 2014). Elevated levels of TNF- $\alpha$ in particular have been shown to cause a reduction in hippocampal volumes through the neurodegenerative TNFRSF1A pathway and can lead to the development of depressive-like behaviour (Eyre et al., 2013). The role of TNFRSF1B has not been thoroughly examined until now.

The purpose of this study was to analyse the TNF- $\alpha$, TNFRSF1A and TNFRSF1B genes on both mRNA and protein levels in patients with $\mathrm{rDD}$, and to investigate the relationship between TNF-a, TNFRSF1 $A$ and TNFRSF1B gene expression and cognitive performance. We hypothesised that levels of TNF-a, TNFRSF1A and TNFRSF1B gene expression are higher in the $\mathrm{rDD}$ group and that this might affect cognitive functions.

\section{MATERIAL AND METHODS}

\section{Subjects}

The study was carried out on a group of 158 subjects aged 20-67 (M=39.86 yrs., S.D.=14.15): patients with rDD $(n=89)$ and a control group of healthy subjects (HS, $n=69)$. Sample recruitment and description have already been presented elsewhere (Talarowska et al., 2014b).

All the patients were native inhabitants of central Poland, unrelated to one another. The individuals for the study group were selected randomly without replacement sampling. The patients were chosen to take part in the experiment based on the inclusion criteria of ICD-10 (F 32.0-7.32.2, F 33.0-F 33.8) (WHO 1993). All the subjects were examined during the course of their hospitalisation. The presence of axis I and II disorders - other than depressive episode - and the diagnosis of somatic diseases and injuries of the central nervous system (CNS), which could have affected cognitive performance, were considered exclusion criteria. In all the subjects participating in the study, case history was obtained before the main study procedure using the standardized Composite International Diagnostic Interview (CIDI) (Patten 1997). The patients from the rDD group were qualified for the study during the process of pharmacological therapy modification. They were treated with agents from the group of selective serotonin reuptake inhibitors (SSRI).

The HS comprised healthy subjects without any family history of psychiatric disorders. The healthy controls included community volunteers who were enrolled based on the criteria of the psychiatric CIDI interview (Patten 1997). The control subjects with psychiatric diagnoses, axis I and II disorders, neurological disorders, or substance abuse or dependence were excluded from the study.
Based on medical records and diagnostic interviews, none of the participants had been diagnosed with a mental disability or any relevant intellectual deficit. All the subjects were free from medical illnesses, including infections and inflammatory or allergic reactions. The control subjects or depressed patients were not treated with the use of the drugs known to influence lipid metabolism, immune responses or endocrine functions. The control subjects had not been taking any medications for at least 2 months prior to blood sampling. None of the healthy participants was a drinker or heavy smoker, and none had ever taken psychotropic drugs.

\section{Methods}

Cognitive function assessment and severity of depression. The neuropsychological assessment was conducted by trained neuropsychologists. A comprehensive neuropsychological test battery was administered to assess the full range of cognitive functions: the Trail Making Test (TMT), the Stroop Test, the Verbal Fluency Test (VFT) and the Auditory Verbal Learning Test (Polish version, AVLT). Depression severity was assessed with the 17-item Hamilton Depression Rating Scale (HDRS). An examination based on neuropsychological tests was conducted once. The assessment of depression symptom intensification with the use of the HDRS scale was performed twice, i.e. at the beginning of the therapy and after 8 weeks. A detailed description of the tests is found in (Lezak 2004) and (Talarowska et al., 2012).

For the patients with rDD, the HDRS, Stroop Test, TMT, AVLT and VFT were performed at the onset of therapy. All patients were examined on admission during the symptomatic phase. At the time of examination, the patients were not taking any medications that would have had an influence on their cognitive function. In the HS group, neuropsychological tests were conducted during a single examination. The same psychologist examined the patients using neuropsychological tests, including an evaluation of the obtained results. The HDRS test was carried out by the same psychiatrist.

Determination of serum TNFRSF1A, TNFRSF1B, $T N F \propto$ level using Enzyme-Linked Immunosorbent Assay (ELISA). For the quantitative detection of circulating serum TNFRSF1 $A$, TNFRSF1B, TNFa actin as control Human TNFRSF1A ELISA Kit (R\&D Systems, Inc Minneapolis MN, USA), Human TNFRSF1B ELISA Kit (Antibodies Atlanta GA, USA), Human TNF $\alpha$ ELISA Kit (R\&D Systems, Inc Minneapolis MN, USA), Human Actin Beta (ACTb) ELISA Kit (Antibodies Atlanta GA, USA) were used. Each serum sample was determined three times. Reactions and calculation of results were performed according to the manufacturer's recommendations. The colour development was stopped (Stop Solution) and the intensity of the colour was measured by Thermo Labsystems Multiskan Ascent 354 from Lab Recyclers at $450 \mathrm{~nm}$ with the correction wavelength set at $540 \mathrm{~nm}$.

Real-time quantitative PCR. Total RNA (1 $\mu \mathrm{g})$ was extracted from blood cells using Trizol reagent (Applied Biosystems), and was processed directly to cDNA synthesis using the TaqMan Reverse Transcription Reagents kit (Applied Biosystem) according to the manufacturer's protocol. The human TNFRSF1 $A$, TNFRSF1B, TNFa and 18S rRNA expression were quantified by real-time quantitative PCR using ABI Prism 7000 Sequence Detection System (Applied Biosystems, Foster City, CA USA) according to the manufacturer's protocol. Briefly, 2.5, 2.0; 1.5, 1.0; 0.5 and 
$0.25 \mu \mathrm{l}$ of synthesised cDNA were amplified in triplicate for $18 \mathrm{~S}$ rRNA and each of the target genes to create a standard curve. Likewise, $2 \mu$ l of cDNA was amplified in triplicate in all isolated samples for each primer/probe combination and $18 \mathrm{~S}$ rRNA. Each sample was supplemented with fluorescent probe Hs01042313_m1, Hs 00961740_m1, Hs 01113624_g1, Hs 04194366-g1, specific for TNFRSF1A, TNFRSF1B, $T N F a, 18 \mathrm{~S}$ rRNA, respectively, and made up to $50 \mu \mathrm{l}$ using TaqMan Universal PCR Master Mix (Applied Biosystems). 18S rRNA cDNA was used as an active and endogenous reference to correct for differences in the amount of total RNA added to reaction and to compensate for different levels of inhibition during reverse transcription of RNA and during PCR. Each target probe was amplified in a separate 96-well plate. All samples were incubated at $50^{\circ} \mathrm{C}$ for 2 minutes and at $95^{\circ} \mathrm{C}$ for 10 minutes, and then cycled at $95^{\circ} \mathrm{C}$ for 30 seconds, $60^{\circ} \mathrm{C}$ for 30 seconds and $72^{\circ} \mathrm{C}$ for $1 \mathrm{~min}$ ute, for 40 cycles. Fluorescence emission data were captured and mRNA levels were quantified using the critical threshold $(\mathrm{Ct})$ value. Analyses were performed with ABI Prism 7000 (SDS Software). Controls without RT and with no template cDNA were performed with each assay. Relative gene expression levels were obtained using the $\Delta \Delta \mathrm{Ct}$ standard $2-\Delta \Delta \mathrm{ct}$ calculations and expressed as a fold change of a control sample (Winer et al., 1999; Livak \& Schmittgen, 2001). Amplification specific transcripts were further confirmed by obtaining melting curve profiles.

Statistical analysis. The statistical analysis of the collected material included calculation of both descriptive and inferential statistics. A two-tailed critical region was employed in the statistical hypothesis testing.

The qualitative characteristics of the experimental and control groups are expressed as frequencies shown as percentages. To characterise the average values for quantitative features, the arithmetical mean $(M)$ was calculated. The measures of statistical dispersion included the range of values between the minimum and the maximum, and the standard deviation (S.D.).

To compare nonparametric variables in the test groups, the following tests were used: the Pearson $\chi^{2}$ for qualitative variables and the Mann-Whitney $U$ test for two independent groups to determine the coincidence of distributions. To evaluate the relationships between the analysed variables, Spearman's R rank order correlation coefficients were estimated. For all analyses, statistical significance was defined as $P<0.05$ (Kirkwood and
Sterne 2003). All data analyses were performed using STATISTICA PL, version 10.

\section{Ethics}

All the patients were native Poles, inhabitants of central Poland and unrelated. Selection of the individuals to the test group was random, without replacement sampling. The experimental group was randomly chosen from the patients treated at the Babinski Memorial Hospital in Lodz. The HS group was selected from among the staff of this hospital.

Before deciding to participate in the study, the subjects were informed of its purpose, assured that the participation was voluntary, and guaranteed that personal data and the results of the tests would be kept confidential. Written informed consent for participation was obtained from each subject according to the study protocol that had been approved by the Bioethical Committee of the Medical University of Lodz (No. RNN/728/12/KB).

\section{RESULTS}

Table 1 presents the characteristics of the study group in terms of sex, age, education (number of years of education) and the course of the disease (rDD group). No statistically significant differences were found between the examined groups in terms of $\operatorname{sex}\left(\chi^{2}=1.32, p=0.249\right)$; the only differences were the number of years of education $(Z=-6.32, p=0.001)$ and age $(Z=8.16, p=0.001)$.

In Table 2 and in graphs 1 and 2 , average values of expression on the mRNA level and on the protein level for TNF, TNFRSF1A, TNFRSF1B genes in the entire examined group $(n=158)$ are shown and the analysed variables are compared in the $\mathrm{rDD}$ group $(\mathrm{n}=89)$ and the group of healthy individuals $(n=69)$.

Statistically significant differences have been observed between the patients with recurrent depressive disorders and the individuals from the HS test group as regards all the analysed variables (Table 2). Expression of TNF, TNFRSF1A, TNFRSF1B genes on the mRNA level and on the protein level was significantly higher in the patients suffering from rDD than in the healthy subjects.

Tables 3-5 present the correlation between TNF, TNFRSF1 $A$ and TNFRSF1B mRNA and protein expression levels and the results of neuropsychological tests, separately for the rDD and HS test group. Tables 3-5 also show the results of the correlation between TNF, TNFRSF1A, TNFRSF1B mRNA and protein expression levels and the neuropsychological tests for the entire group.

Table 1. Demographic characteristics of the group with rDD in comparison to the HS group, and data concerning the course of the disease

\begin{tabular}{|c|c|c|c|c|c|c|c|}
\hline \multirow{2}{*}{$\begin{array}{l}\text { Characteristics } \\
\mathrm{N}\end{array}$} & & \multicolumn{3}{|c|}{ rDD $(n=89)$} & \multicolumn{3}{|c|}{ HS (n=69) } \\
\hline & & $\%$ & ( \pm S.D.) & $\mathrm{n}$ & $\%$ & ( \pm S.D.) & \\
\hline \multirow{2}{*}{ Sex } & Female & 50 & 56.18 & - & 45 & 65.22 & - \\
\hline & Male & 39 & 43.82 & - & 24 & 34.78 & - \\
\hline Age (yrs) & & - & - & $48.23( \pm 11.49)$ & - & - & $29.06( \pm 9.01)$ \\
\hline \multirow{3}{*}{ Education level } & Primary & 26 & 29.21 & - & - & - & - \\
\hline & Secondary & 50 & 56.18 & - & 26 & 37.68 & - \\
\hline & College/University & 13 & 14.61 & - & 43 & 62.32 & - \\
\hline \multirow{2}{*}{ rDD } & Disease duration in years & - & - & $7.01( \pm 5.54)$ & - & - & - \\
\hline & Number of depression episodes & - & - & $5.15( \pm 1.98)$ & - & - & - \\
\hline
\end{tabular}

rDD, recurrent depressive disorders; HS, healthy subjects; $n$, number of samples; \%, percentage; \pm S.D., standard deviation. 
Table 2. Expression on the protein level and on the level of mRNA for TNF, TNFRSF1A, TNFRSF1B genes in the examined group

\begin{tabular}{|c|c|c|c|c|c|}
\hline \multirow{2}{*}{ Variable } & \multirow{2}{*}{$\begin{array}{c}n=158 \\
M(S . D .)\end{array}$} & \multirow{2}{*}{$\begin{array}{c}\text { rDD } \\
n=89\end{array}$} & \multirow{2}{*}{$\begin{array}{c}\begin{array}{c}H S \\
n=69\end{array} \\
M(S . D .)\end{array}$} & \multicolumn{2}{|c|}{ Mann-Whitney U test } \\
\hline & & & & Z & $p$ \\
\hline TNF protein $(\mathrm{pg} / \mathrm{ml})$ & $\begin{array}{c}8.22 \\
(3.53)\end{array}$ & $\begin{array}{l}11.16 \\
(1.31)\end{array}$ & $\begin{array}{c}4.47 \\
(0.99)\end{array}$ & 10.736 & $<0.001^{*}$ \\
\hline $\begin{array}{l}\text { TNF mRNA } \\
\left(2^{-\Delta \Delta c t)}\right.\end{array}$ & $\begin{array}{c}0.47 \\
(0.24)\end{array}$ & $\begin{array}{c}0.68 \\
(0.09)\end{array}$ & $\begin{array}{c}0.19 \\
(0.05)\end{array}$ & 10.736 & $<0.001^{*}$ \\
\hline $\begin{array}{l}\text { TNFRSF1A } \\
\text { protein (pg/ml) }\end{array}$ & $\begin{array}{l}1188.92 \\
(206.19)\end{array}$ & $\begin{array}{c}1351.01 \\
(77.66)\end{array}$ & $\begin{array}{c}982.20 \\
(111.63)\end{array}$ & 10.707 & $<0.001^{*}$ \\
\hline $\begin{array}{l}\text { TNFRSF1A } \\
\text { mRNA } \\
\left(2^{-\Delta \Delta c t)}\right.\end{array}$ & $\begin{array}{c}1.29 \\
(0.11)\end{array}$ & $\begin{array}{c}1.38 \\
(0.04)\end{array}$ & $\begin{array}{c}1.19 \\
(0.06)\end{array}$ & 10.679 & $<0.001^{*}$ \\
\hline $\begin{array}{l}\text { TNFRSF1B } \\
(\mathrm{pg} / \mathrm{ml})\end{array}$ & $\begin{array}{l}1977.09 \\
(208.11)\end{array}$ & $\begin{array}{c}2136.19 \\
(97.04)\end{array}$ & $\begin{array}{l}1774.17 \\
(113.01)\end{array}$ & 10.499 & $<0.001^{*}$ \\
\hline $\begin{array}{l}\text { TNFRSF1B } \\
\text { mRNA } \\
\left(2^{-\Delta \Delta c t)}\right.\end{array}$ & $\begin{array}{c}1.68 \\
(0.11)\end{array}$ & $\begin{array}{c}1.76 \\
(0.05)\end{array}$ & $\begin{array}{c}1.58 \\
(0.07)\end{array}$ & 10.187 & $<0.001^{*}$ \\
\hline
\end{tabular}

TNF, tumour necrosis factor; TNFRSF1A, tumour necrosis factor receptor superfamily member $1 \mathrm{~A}$; TNFRSF1B, tumour necrosis factor receptor superfamily member $1 B$; rDD, recurrent depressive disorders; HS, healthy subjects; M, mean; S.D., standard deviation; ${ }^{*} p$, statistically significant.

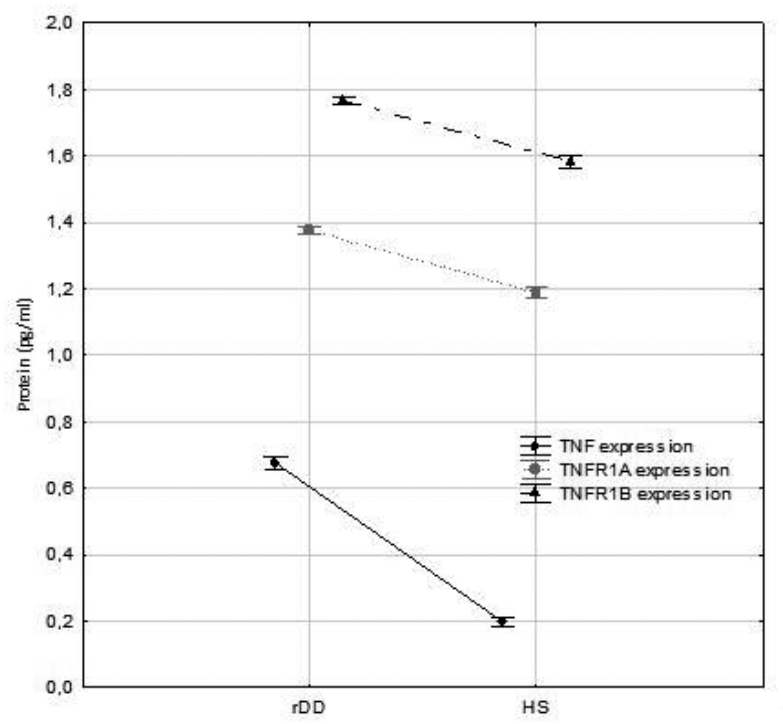

Figure 1. Average values and confidence interval (95.00\%) for the analysed variables.

rDD, recurrent depressive disorders; HS, healthy subjects

No statistically significant correlations were observed between the analysed variables in both the rDD group and the HS test group. The only exception was noticed in the HS test group, where increased expression of TNFRSF1 $A$ and TNFRSF1B gene correlated negatively with the performance of the AVLT test. However, statistically significant correlations between TNF, TNFRSF1A, TNFRSF1B mRNA gene expression levels and all the neuropsychological tests used in the survey for the entire group $(n=158)$ were observed.

\section{DISCUSSION}

In recent years, an increasing number of scientific reports support the immunological hypothesis of depression. This emphasises the role of the immune system in the aetiology, course and recurrence of the disease (Maes et al., 2013). Many authors who analyse this prob-

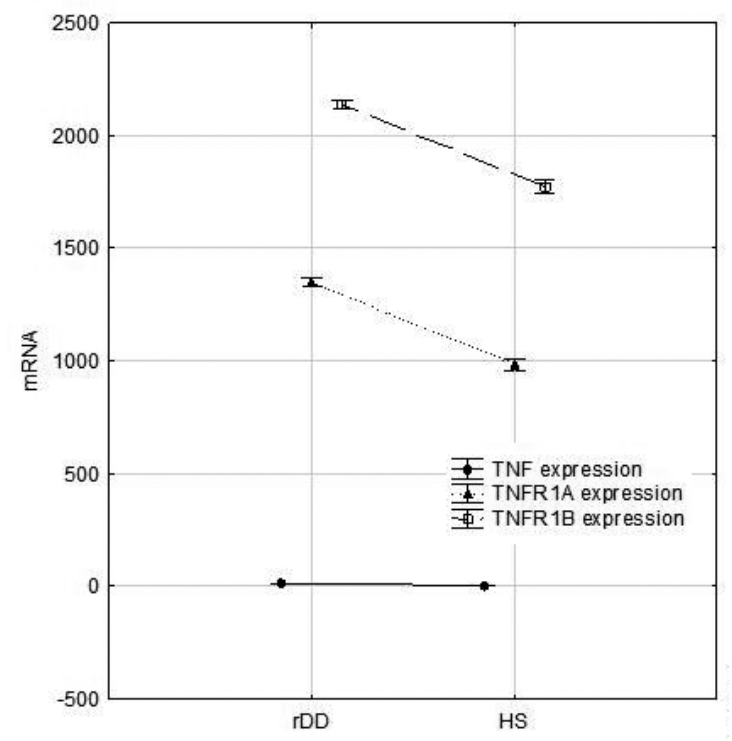

Figure 2. Average values and confidence interval (95.00\%) for the analysed variables.

$\mathrm{rDD}$, recurrent depressive disorders; $\mathrm{HS}$, healthy subjects

lem pay attention mainly to the role of proinflammatory cytokines in behavioural changes, within the systems of neurotransmitters in CNS and in endocrine changes observed in depression. Moreover, the varying course of depressive disorders is justified by the inflammatory mechanisms and immunological disorders that lie at the foundation of the disorders (Maes et al., 2013).

The hypothesis presented by the authors in the introduction was confirmed. The obtained results indicate a difference between the level of TNF, TNFRSF1A and TNFRSF1B gene expression on both mRNA level and protein level between the group of patients with rDD and the reference group. The people suffering from recurrent depressive disorders were characterised by higher expression of all the genes on the protein level and on the mRNA level than the group of healthy subjects. The results obtained are in agreement with the results of experiments conducted by Dannehl and cow- 
Table 3. Spearman's rank correlation coefficients(R) for the variables tested - TNF

\begin{tabular}{|c|c|c|c|c|c|c|}
\hline & \multicolumn{2}{|l|}{ rDD $(n=89)$} & \multicolumn{2}{|l|}{ HS $(n=69)$} & \multicolumn{2}{|c|}{$\begin{array}{l}\text { The whole } \\
\text { group }(n=158)\end{array}$} \\
\hline & $\begin{array}{l}\text { TNF mRNA } \\
\left(2-\Delta \Delta^{\mathrm{ct}}\right) \\
0.68(0.09)\end{array}$ & $\begin{array}{l}\text { TNF protein } \\
\text { (pg/ml) } \\
11.16(1.31)\end{array}$ & $\begin{array}{l}\text { TNF mRNA } \\
\left(2-\Delta \Delta^{\mathrm{ct}}\right) \\
0.19(0.05)\end{array}$ & $\begin{array}{l}\text { TNF protein } \\
(\mathrm{pg} / \mathrm{ml}) \\
4.47(0.99)\end{array}$ & $\begin{array}{l}\text { TNF mRNA } \\
\left(2-\Delta \Delta^{\mathrm{ct}}\right) \\
0.47(0.24)\end{array}$ & $\begin{array}{l}\text { TNF protein } \\
(\mathrm{pg} / \mathrm{ml}) \\
8.22(3.53)\end{array}$ \\
\hline & \multicolumn{2}{|r|}{$\mathrm{R}$} & \multicolumn{2}{|c|}{$\mathrm{R}$} & \multicolumn{2}{|c|}{$\mathrm{R}$} \\
\hline TMT A-time & -0.032 & 0.001 & -0.004 & 0.013 & $0.482^{*}$ & $0.472^{*}$ \\
\hline TMT B-time & -0.072 & -0.034 & 0.087 & 0.100 & $0.595^{*}$ & $0.585^{*}$ \\
\hline RCNb-time & -0.091 & -0.081 & 0.117 & 0.135 & $0.487^{*}$ & $0.483^{*}$ \\
\hline NCWd-time & -0.198 & -0.163 & 0.210 & 0.234 & $0.483^{*}$ & $0.466^{*}$ \\
\hline VFT-animals & -0.037 & -0.016 & 0.079 & 0.079 & $-0.443^{*}$ & $-0.447^{*}$ \\
\hline VFT-sharp objects & 0.113 & 0.084 & -0.010 & -0.022 & $-0.333^{*}$ & $-0.323^{*}$ \\
\hline VFT-the letter k & -0.093 & -0.111 & 0.028 & 0.035 & $-0.386^{*}$ & $-0.381^{*}$ \\
\hline AVLT-first attempt & -0.124 & -0.151 & -0.203 & $-0,186$ & $-0.507^{*}$ & $-0.503^{*}$ \\
\hline AVLT-number of words in $30 \mathrm{~min}$ & -0.018 & -0.041 & 0.144 & 0.167 & $-0.507^{*}$ & $-0.505^{*}$ \\
\hline AVLT-average of 5 tests & -0.104 & -0.111 & -0.190 & -0.167 & $-0.599^{*}$ & $-0.601^{*}$ \\
\hline
\end{tabular}

TNFRSF1A, tumour necrosis factor receptor superfamily member $1 \mathrm{~A}$; rDD, recurrent depressive disorder; HS, healthy subjects; TMT, Trail Making Test; RCNb, reading colour names in black; NCWd, naming colour of word-different; AVLT, Auditory-Verbal Learning Test; VFT, Verbal Fluency Test; ${ }^{*} p$, statistically significant.

Table 4. Spearman's rank correlation coefficients(R) for the variables tested - TNFRSF1A

\begin{tabular}{|c|c|c|c|c|c|c|}
\hline & \multicolumn{2}{|l|}{ rDD $(n=89)$} & \multicolumn{2}{|l|}{ HS (n=69) } & \multicolumn{2}{|c|}{$\begin{array}{l}\text { The whole } \\
\text { group }(n=158)\end{array}$} \\
\hline & $\begin{array}{l}\text { TNFRSF1A } \\
\text { mRNA } \\
\left(2-\Delta \Delta^{\mathrm{ct})}\right. \\
1.38(0.04)\end{array}$ & $\begin{array}{l}\text { TNFRSF1A } \\
\text { protein }(\mathrm{pg} / \mathrm{ml}) \\
1351.01(77.66)\end{array}$ & $\begin{array}{l}\text { TNFRSF1A } \\
\text { mRNA } \\
\left(2-\Delta \Delta^{\mathrm{ct})}\right. \\
1.19(0.06)\end{array}$ & $\begin{array}{l}\text { TNFRSF1A } \\
\text { protein } \\
\text { (pg/ml) } \\
982.20(111.63)\end{array}$ & $\begin{array}{l}\text { TNFRSF1A } \\
\text { mRNA } \\
\left(2-\Delta \Delta^{\mathrm{ct})}\right. \\
1.29(0.11)\end{array}$ & $\begin{array}{l}\text { TNFRSF1A } \\
\text { protein } \\
\text { (pg/ml) } \\
1188.92(206.19)\end{array}$ \\
\hline & \multicolumn{2}{|r|}{$\mathrm{R}$} & \multicolumn{2}{|r|}{$\mathrm{R}$} & \multicolumn{2}{|r|}{$\mathrm{R}$} \\
\hline TMT A-time & 0.001 & 0.037 & 0.059 & 0.103 & $0.485^{*}$ & $0.502^{*}$ \\
\hline TMT B-time & -0.031 & -0.002 & 0.136 & 0.163 & $0.593^{*}$ & $0.602 *$ \\
\hline RCNb-time & -0.018 & 0.033 & 0.068 & 0.088 & $0.492^{*}$ & $0.514^{*}$ \\
\hline NCWd-time & -0.145 & -0.082 & -0.044 & -0.012 & $0.438^{*}$ & $0.463^{*}$ \\
\hline VFT-animals & 0.040 & -0.020 & 0.109 & 0.068 & $-0.412^{*}$ & $-0.441^{*}$ \\
\hline VFT-sharp objects & 0.018 & -0.019 & -0.029 & -0.087 & $-0.355^{*}$ & $-0.376^{*}$ \\
\hline VFT-the letter k & -0.089 & -0.087 & -0.097 & -0.120 & $-0.403^{*}$ & $-0.403^{*}$ \\
\hline AVLT-first attempt & -0.117 & -0.154 & -0.199 & -0.174 & $-0.492^{*}$ & $-0.506^{*}$ \\
\hline $\begin{array}{l}\text { AVLT-number of words } \\
\text { in } 30 \mathrm{~min}\end{array}$ & 0.016 & -0.006 & -0.089 & -0.104 & $-0.527^{*}$ & $-0.538^{*}$ \\
\hline AVLT-average of 5 tests & -0.009 & -0.077 & $-0.256^{*}$ & $-0.268^{*}$ & $-0.579^{*}$ & $-0.603^{*}$ \\
\hline
\end{tabular}

TNF, tumour necrosis factor; rDD, recurrent depressive disorder; HS, healthy subjects; TMT, Trail Making Test; RCNb, reading colour names in black; NCWd, naming colour of word-different; AVLT, Auditory-Verbal Learning Test; VFT, Verbal Fluency Test; * $p$ statistically significant.

orkers (2014) and other authors (Khairova et al., 2009; Dowlat et al., 2010; Becking et al., 2013; Mills et al., 2013; Schmidt et al., 2014; Mihailova et al., 2016; Park et al., 2016).

The first reports indicating the participation of proinflammatory cytokines in the pathogenesis of depression resulted from observations of mental changes in laboratory-tested animals and in people after administering, among others, TNF- $\alpha$. In the tested groups the following symptoms were noticed: loss of appetite, fatigue, low mood, or reduced efficiency of cognitive processes (mainly the efficiency of memory and attention processes) (Dantzer, 2009). According to Maes and coworkers (2012), the concentration of TNF- $\alpha$ in blood serum of the affected with symptoms of depressive disorders is, however, significantly greater than in the group of patients with chronic fatigue syndrome (CFS). In several papers it is possible to find confirmation of the relationship between increased levels of TNF- $\alpha$ and the intensified tendency towards making suicidal attempts. This correlation is observed among both adults and teens (Serafini et al., 2013; O'Donovan et al., 2013). What is interesting, Grosse and coworkers (2016) suggest a linear relationship between childhood sexual abuse and increased pro-inflammatory cytokine levels in depressive patients, while more recent stressful life events are not related to these inflammatory markers. The last of the conclusions seems to support the neurodevelopmental 
Table 5. Spearman's rank correlation coefficients(R) for the variables tested - TNFRSF1B

\begin{tabular}{|c|c|c|c|c|c|c|}
\hline & \multicolumn{2}{|l|}{ rDD $(n=89)$} & \multicolumn{2}{|l|}{ HS (n=69) } & \multicolumn{2}{|l|}{$\begin{array}{l}\text { The whole } \\
\text { group }(n=158)\end{array}$} \\
\hline & $\begin{array}{l}\text { TNFRSF1B } \\
\text { mRNA }\left(2-\Delta \Delta^{\mathrm{ct}}\right) \\
1.76(0.05)\end{array}$ & $\begin{array}{l}\text { TNFRSF1B } \\
\text { protein }(\mathrm{pg} / \mathrm{ml}) \\
2136.19(97.04)\end{array}$ & $\begin{array}{l}\text { TNFRSF1B } \\
\text { mRNA }\left(2-\Delta \Delta^{\mathrm{ct}}\right) \\
1.58(0.07)\end{array}$ & $\begin{array}{l}\text { TNFRSF1B } \\
\text { protein }(\mathrm{pg} / \mathrm{ml}) \\
1774.17(113.01)\end{array}$ & $\begin{array}{l}\text { TNFRSF1B } \\
\text { mRNA }(2-\Delta \Delta \mathrm{ct}) \\
1.68(0.11)\end{array}$ & $\begin{array}{l}\text { TNFRSF1B } \\
\text { protein }(\mathrm{pg} / \mathrm{ml}) \\
1977.09(208.11)\end{array}$ \\
\hline & \multicolumn{2}{|r|}{$\mathrm{R}$} & \multicolumn{2}{|r|}{$\mathrm{R}$} & \multicolumn{2}{|r|}{$\mathrm{R}$} \\
\hline TMT A-time & 0.011 & 0.016 & 0.073 & 0.102 & $0.453^{*}$ & $0.485^{*}$ \\
\hline TMT B-time & -0.011 & 0.011 & 0.127 & 0.151 & $0.565^{*}$ & $0.601^{*}$ \\
\hline RCNb-time & 0.017 & 0.009 & 0.082 & 0.067 & $0.489 *$ & $0.488^{*}$ \\
\hline NCWd-time & -0.061 & -0.061 & -0.056 & -0.032 & $0.437^{*}$ & $0.456^{*}$ \\
\hline VFT -animals & -0.041 & -0.059 & 0.043 & 0.064 & $-0.431^{*}$ & $-0.452^{*}$ \\
\hline VFT-sharp objects & 0.045 & 0.041 & -0.157 & -0.085 & $-0.358^{*}$ & $-0.353^{*}$ \\
\hline VFT-the letter k & -0.075 & -0.096 & -0.098 & -0.094 & $-0.383^{*}$ & $-0.406^{*}$ \\
\hline AVLT-first attempt & -0.061 & -0.053 & $-0.289^{*}$ & -0.183 & $-0.481^{*}$ & $-0.464^{*}$ \\
\hline $\begin{array}{l}\text { AVLT-number of } \\
\text { words in } 30 \mathrm{~min}\end{array}$ & -0.051 & -0.073 & -0.118 & -0.096 & $-0.523^{*}$ & $-0.549^{*}$ \\
\hline $\begin{array}{l}\text { AVLT-average of } 5 \\
\text { tests }\end{array}$ & -0.071 & -0.069 & $-0.301^{*}$ & $-0.267^{*}$ & $-0.578^{*}$ & $-0.586^{*}$ \\
\hline
\end{tabular}

TNFRSF1B, tumour necrosis factor receptor superfamily member 1B; rDD, recurrent depressive disorder; HS, healthy subjects; TMT, Trail Making Test; RCNb, reading colour names in black; NCWd, naming colour of word-different; AVLT, Auditory-Verbal Learning Test; VFT, Verbal Fluency Test; ${ }^{*} p$ statistically significant.

theory of depression development (Gałecki \& Talarows$\mathrm{ka}, 2016)$.

The direct relationship between inflammatory processes and the development of depression is also indicated in the papers which evaluate the level of TNF- $\alpha$ in blood serum of patients suffering from other diseases, including Alzheimer's disease (AD), with or without an accompanying diagnosis of depression. The serum levels of $\mathrm{TNF}-\alpha$ were elevated in $\mathrm{AD}$ patients with depression compared to the control group or AD patients without depression. Furthermore, a strong inverse correlation was observed between MMSE (MiniMental State Examination) scores and serum levels of TNF- $\alpha$ in AD subjects with depression (Khemka et al., 2014). In addition, depressive disorders have frequently been observed in association with peripheral inflammatory cytokine activation in several medical conditions, including viral infections, rheumatoid arthritis, coronary heart disease, metabolic disorders (diabetes type 1 and type 2) or cancer (El-Tantawy et al., 2008; Oliveira Miranda et al., 2014; Singhal et al., 2014), as well as among pregnant women, in whom the presence of symptoms of depressive disorders had been noticed (Christian et al., 2011). The hypothesis of an elevated level of $\mathrm{TNF}_{-} \alpha$ as a consequence of active stressors (e.g. experiencing domestic violence in childhood) has also been confirmed several times (Kiecolt-Glaser et al., 2011; Himmerich et al., 2013). Elevated concentrations of TNF- $\alpha$ in blood serum have been noticed among patients diagnosed with obsessive-compulsive disorder (OCD) (Fontenelle et al., 2012). It is necessary to mention that an increased level of $\mathrm{TNF}-\alpha$ is observed in the patients suffering from depression accompanying medical conditions characterised by a chronic inflammatory component such as breast cancer (Bower et al., 2011) and cardiovascular diseases (Szczepańska-Sadowska et al., 2010). It is, however, possible to find papers in which the said relationship (depression symptoms and TNF- $\alpha$ level increase) is not confirmed (Simpson et al., 2016).
The presented study also provides an evaluation of the relationship between $\mathrm{TNF}-\alpha$ gene expression and cognitive functions.

In the case of the entire group tested ( $n=158)$, a negative influence of increased expression of TNF genes on the efficiency of all the analysed variables has been indicated: operational memory (visual and spatial, and verbal and auditory), speed of information processing, attention, short-term memory, and the ability of acquiring new information (declarative memory).

There are not many experiments that would analyse the correlation between TNF gene expression and gene expression for its receptors, and the cognitive functions of the patients with rDD. Referring to the available literature, it is worth quoting the work by Naude and coworkers (2014), in which the functional roles of TNFRSF1A and TNFRSF1B in learning and memory, motor performance and anxiety-like behaviour were analysed. Results from this study show that deletion of TNFRSF1B impairs novel object recognition, spatial memory recognition, contextual fear conditioning, and motor performance, and can increase anxiety-like behaviour in young adult mice. However, the results presented by us do not differentiate the level of performing the neuropsychological tests depending on the expression of the gene that encodes the TNFRSF1A or TNFRSF1B receptor. Increased expression of both the genes is negatively correlated with cognitive performance.

At this point it is worth mentioning the research studies by Smagula and coworkers (2016). The authors demonstrated that immunological markers are associated with brain structure in late-life depression. TNF- $\alpha$ had a significant positive relationship with white matter hyperintensity volume (WMH), but only eotaxin was associated with the executive function (set-shifting performance as measured with the Trail-making test).

Providing a response to the question concerning the cause of the mentioned relationships is not an easy task. The results of experiments carried out in recent years show that proinflammatory cytokines (including TNF) 
are constitutively expressed in normal brain, although not so long ago there was an opinion that inflammatory cytokines were only expressed in the brain in response to pathological stimuli (Khairova et al., 2009).

TNF is a proinflammatory cytokine, which is released during neuronal activity and plays a crucial role in regulating the strength of synaptic transmission (Marin \& Kipnis, 2013). TNF has also been shown to inhibit longterm potentiation (LTP) and synaptic plasticity in the hippocampus and potentially contribute to excitotoxicity (Pickering \& O’Connor, 2007). According to Butler and coworkers (2004), the pathophysiological levels of TNF- $\alpha$ have been shown to inhibit LTP in the CA1 region, as well as the dentate gyrus of the rat hippocampus.

TNF signalling through the TNFR1 receptor modulates synaptic strength by changing the expression of AMPA receptors (AMPAR, synaptic $\alpha$-amino-3-hydroxy5-methyl-4-isoxazolepropionic acid receptors) in the postsynaptic compartment (Dummer et al., 2002). Gliasecreted TNF was identified as an important factor in mediating synaptic scaling (Stellwagen \& Malenka, 2006). TNF also seems to play a role in adult hippocampal neurogenesis (Iosif et al., 2006). Signalling through TNFRSF1A seems to act as a negative regulator of neurogenesis, as its deletion results in an increase in the number of newly produced neurons, whereas TNFRSF1B signalling is a positive regulator, as indicated by the drop in neurogenesis following its deletion (Jurgens et al., 2012).

Moreover, Sudheimer and coworkers (2014) have demonstrated that elevated levels of waking cortisol in conjunction with higher concentrations of TNF- $\alpha$ are associated with smaller hippocampal volumes among older adults. In addition, independent of cortisol, higher levels of TNF- $\alpha$ are also associated with smaller hippocampal volumes. Authors (Sudheimer et al., 2014) suggest that the dynamic balance between the hypothalamic-pituitary adrenal axis and inflammation processes may explain hippocampal volume reductions. Similar results, indicating the negative relationship between the level of proinflammatory cytokines (including TNF- $\alpha$ ) and the cognitive function, have been obtained by Jurgens and coworkers (2012) (experiments based on an animal model). Additionally, Pandey and coworkers (2012) reported increased expression of the TNF- $\alpha$ encoding gene in the area of the prefrontal cortex (field 10 according to Brodmann) among 24 victims of suicide attempts. This correlation was statistically greater among the victims of suicide attempts than 24 individuals from the reference group (similar results were also obtained by Janelidze and coworkers, 2011). It has been known for a long time that the prefrontal cortex is particularly active in a series of mental processes connected with planning and executing actions, and the so-called executive functions, and their weakening has been demonstrated many times among patients suffering from rDD (Talarowska et al., 2013).

The significant relationships observed in the current study between TNF gene expression and cognitive efficiency suggest that immune disturbance may be involved in cognitive deficits. The presented results also indicate that immuno-inflammatory processes may play a central role in cognitive deficits, not only in depressive disorders. Future studies with larger arrays of cytokine profiles may provide more sensitive and specific modes of diagnostics in determining rDD aetiology and provide guidance in individual therapies (Young et al., 2014; Dahl et al., 216; Park et al., 2016).

\section{CONCLUSIONS}

1. The results of our study show increased expression of the TNF, TNFRSF1 $A$ and TNFRSF1B genes on both mRNA and protein levels in depression. 2. Elevated expression of TNF- $a$, TNFRSF1 $A$ and TNFRSF1B correlates negatively with cognitive efficiency: working memory, executive functions, attention functions, direct and delayed auditory-verbal memory, effectiveness of learning processes and verbal fluency.

\section{Limitations}

The number of patients and healthy subjects may result in the lack of statistical significance in some cases, which is the limitation affecting the conclusions of our study.

Additionally, the difference in the level of education and the differences in mean age of the examined subjects may be significant for the analysis of the obtained results.

\section{Competing interests}

None to declare.

\section{Acknowledgements}

This study was supported with scientific research grants from the National Science Centre, No. DEC. 2012/07/B/NZ7/04212 and from Medical University of Lodz, no. 503/5-062-02/503-51-006 and no. 502-03/5062-02/502-54-125.

\section{REFERENCES}

Anisman H (2009) Cascading effects of stressors and inflammatory immune system activation: implications for major depressive disorder. J Psychiatry Neurosci 34: 4-20

Becking K, Boschloo L, Vogelzangs N, Haarman BC, Riemersma-van der Lek R, Penninx BW, Schoevers RA (2013) The association between immune activation and manic symptoms in patients with a depressive disorder. Transl Psychiatry 3: e314. http://doi. org/10.1038/tp.2013.87

Besedovsky HO, del Rey A (2000) The cytokine-HPA axis feed-back circuit. Z. Rheumatol 59 (Suppl 2): 26-30

Bower JE, Ganz PA, Irwin MR, Kwan L, Breen EC, Cole SW (2011) Inflammation and behavioral symptoms after breast cancer treatment: do fatigue, depression, and sleep disturbance share a common underlying mechanism? J Clin Oncol 29: 3517-3522. http://doi. org/10.1200/JCO.2011.36.1154

Butler MP, O'Connor JJ, Moynagh PN (2004) Dissection of tumor-necrosis factor-alpha inhibition of long-term potentiation (LTP) reveals a p38 mitogen-activated protein kinase-dependent mechanism which maps to early-but not late-phase LTP. Neurosci 124: 319-26. http://doi.org/10.1016/j.neuroscience.2003.11.040

Christian LM, Glaser R, Porter K, Malarkey WB, Beversdorf D, Kiecolt-Glaser JK (2011) Poorer self-rated health is associated with elevated inflammatory markers among older adults. Psychoneuroendocrinology 36: 1495-1504. http://doi.org/10.1016/j.psyneuen.2011.04.003

Dahl J, Ormstad H, Aass HC, Sandvik L, Malt UF, Andreassen OA (2016) Recovery from major depressive disorder episode after non-pharmacological treatment is associated with normalized cytokine levels. Acta Psychiatr Scand 134: 40-47. http://doi.org/10.1111/ acps. 12576

Dannehl K, Rief W, Schwarz MJ, Hennings A, Riemer S, Selberdinger V, Stapf T, Euteneuer F (2014) The predictive value of somatic and cognitive depressive symptoms for cytokine changes in patients with major depression. Neuropsychiatr Dis Treat 10: 1191-1197. http://doi. org/10.2147/NDT.S61640

Dantzer R (2009) Cytokine, sickness behavior, and depression. Immunol Allergy Clin North Am 29: 247-264. http://doi.org/10.1016/j. iac.2009.02.002

Dantzer R, O'Connor JC, Freund GG, Johnson RW, Kelley KW (2008) From inflammation to sickness and depression: when the immune system subjugates the brain. Nat Rev Neurosci 9: 46-46. http://doi.org/10.1038/nrn2297 
Dowlati Y, Herrmann N, Swardfager W, Liu H, Sham L, Reim EK, Lanctôt KL (2010) A meta-analysis of cytokines in major depression. Biol Psychiatry 67: 446-447. http://doi.org/10.1016/j.biopsych.2009.09.033

Dummer W, Niethammer AG, Baccala R, Lawson BR, Wagner N, Reisfeld RA, Theofilopoulos AN (2002) T cell homeostatic proliferation elicits effective antitumor autoimmunity. J Clin Invest 110: 185-192. http://doi.org/10.1172/JCI15175

El-Tantawy AM, El-Sayed AE, Kora BA, Amin RT (2008) Psychiatric morbidity associated with some cytokines (IL-1beta, IL-12, IL-18 and TNF-alpha) among rheumatoid arthritis patients. Egypt J Immunol 15: 1-11.

Eyre H, Papps E, Baune BT (2013) Treating depression and depression-like behavior with physical activity: an immune perspective. Front Psychiatry 4: 3. http://doi.org/10.3389/fpsyt.2013.00003

Figueroa-Vega N, Moreno-Frías C, Malacara JM (2015) Alterations in adhesion molecules, pro-inflammatory cytokines and cell-derived microparticles contribute to intima-media thickness and symptoms in postmenopausal women. PLoS One 10: e0120990. http://doi. org/10.1371/journal.pone.0120990

Fontenelle LF, Barbosa IG, Luna JV, de Sousa LP, Abreu MN, Teixeira AL (2012) A cytokine study of adult patients with obsessive-compulsive disorder. Compr Psychiatry 53: 797-804. http://doi. org/10.1016/j.comppsych.2011.12.007

Gałecki P, Talarowska M (2016) The evolutionary theory of depression. Med Sci Monit (in press). http://doi.org/10.12659/MSM.901240

Grosse L, Ambrée O, Jörgens S, Jawahar MC, Singhal G, Stacey D, Arolt V, Baune BT (2016) Cytokine levels in major depression are related to childhood trauma but not to recent stressors. Psychoneuroendocrinology 73: 24-31. http://doi.org/10.1016/j.psyneuen.2016.07.205

Hannestad J, DellaGioia N, Bloch M (2011) The effect of antidepressant medication treatment on serum levels of inflammatory cytokines: a meta-analysis. Neuropsychopharmacology 36: 2452-2459. http://doi.org/10.1038/npp.2011.132

Himmerich H, Fischer J, Bauer K, Kirkby KC, Sack U, Krügel U (2013) Stress-induced cytokine changes in rats. Eur Cytokine Netw 2: 97-103. http://doi.org/10.1684/ecn.2013.0338

ICD-10 Classification of Mental \& Behavioural Disorders (1993) World Health Organization, Genewa

Iosif RE, Ekdahl CT, Ahlenius H, Pronk CJ, Bonde S, Kokaia Z, Jacobsen SE, Lindvall O (2006) Tumor necrosis factor receptor 1 is a negative regulator of progenitor proliferation in adult hippocampal neurogenesis. J Neurosci 26: 9703-9712. http://doi.org/10.1523/ JNEUROSCI.2723-06.2006

Janelidze S, Mattei D, Westrin A, Traskman-Bendz L, Brundin L (2011) Cytokine levels in the blood may distinguish suicide attempters from depressed patients. Brain, Behavior and Immunity 25: 335339. http://doi.org/10.1016/j.bbi.2010.10.010

Jurgens HA, Amancherla K, Johnson RW (2012) Influenza infection induces neuroinflammation, alters hippocampal neuron morphology, and impairs cognition in adult mice. J Neurosci 32: 3958-3968. http://doi.org/10.1523/JNEUROSCI.6389-11.2012

Khairova RA, Machado-Vieira R, Du J, Manji HK (2009) A potential role for pro-inflammatory cytokines in regulating synaptic plasticity in major depressive disorder. Int J Neuropsychopharmacol 12: 561-568. http://doi.org/10.1017/S1461145709009924

Khemka VK, Ganguly A, Bagchi D, Ghosh A, Bir A, Biswas A, Chattopadhyay S, Chakrabarti S (2014) Raised serum proinflammatory cytokines in Alzheimer's disease with depression. Aging Dis 5: $170-$ 176. http://doi.org/10.14336/AD.2014.0500170

Kiecolt-Glaser JK, Gouin JP, Weng NP, Malarkey WB, Beversdorf DQ, Glaser R (2011) Childhood adversity heightens the impact of later-life caregiving stress on telomere length and inflammation. Psychosom Med 73: 16-22. http://doi.org/10.1097/PSY.0b013e31820573b6

Kirkwood B, Sterne J (2003) Essential medical statistics, 2nd edn. Wiley-Bleckwell.

Lanquillon S, Krieg JC, Bening-Abu-Shach U, Vedder H (2000) Cytokine production and treatment response in major depressive disorder. Neuropsychopharmacology 22: 370-379. http://doi.org/10.1016/ S0893-133X(99)00134-7

Lezak MD (2004) Neuropsychological Assessment. Oxford University Press, New York, Oxford.

Lichtblau N, Schmidt FM, Schumann R, Kirkby KC, Himmerich H (2013) Cytokines as biomarkers in depressive disorder: current standing and prospects. Int Rev Psychiatry 25: 592-603. http://doi.or $\mathrm{g} / 10.3109 / 09540261.2013 .813442$

Livak KJ, Schmittgen TD (2001) Analysis of relative gene expression data using real-time quantitative PCR and the 2(-Delta Delta C(T)) Method. Methods 25: 402-408. http://doi.org/10.1006/ meth.2001.1262

Maes M, Bosmans E, Suy E, Vandervorst C, De Jonckheere C, Raus J (1990-1991) Immune disturbances during major depression: upregulated expression of interleukin-2 receptors. Neuropsychobiology 24: $115-120$.

Maes M, Kubera M, Leunis JC, Berk M, Geffard M, Bosmans E (2013) In depression, bacterial translocation may drive inflamma- tory responses, oxidative and nitrosative stress (O\&NS), and autoimmune responses directed against O\&NS-damaged neoepitopes. Acta Psychiatr Scand 127: 344-354. http://doi.org/10.1111/j.16000447.2012.01908.x

Maes M, Twisk FN, Ringel K (2012) Inflammatory and cell-mediated immune biomarkers in myalgic encephalomyelitis/chronic fatigue syndrome and depression: inflammatory markers are higher in myalgic encephalomyelitis/chronic fatigue syndrome than in depression. Psychother Psychosom 81: 286-295. http://doi.org/10.1159/000336803

Marin I, Kipnis J (2013) Learning and memory ... and the immune system. Learn Mem 20: 601-606. http://doi.org/10.1101/lm.028357.112

Michie HR, Spriggs DR, Manogue KR, Sherman ML, Revhaug A, O’Dwyer ST, Arthur K, Dinarello CA, Cerami A, Wolff SM (1988) Tumor necrosis factor and endotoxin induce similar metabolic responses in human beings. Surgery 104: 280-286

Mihailova S, Ivanova-Genova E, Lukanov T, Stoyanova V, Milanova V, Naumova E (2016) A study of TNF- $\alpha$, TGF- $\beta$, IL-10, IL-6, and IFN- $\gamma$ gene polymorphisms in patients with depression. I Neuroimmunol 293: 123-128. http://doi.org/10.1016/j.jneuroim.2016.03.005

Mikova O, Yakimova R, Bosmans E, Kenis G, Maes M (2001) Increased serum tumor necrosis factor alpha concentrations in major depression and multiple sclerosis. Eur Neuropsychopharmacol 11: 203-208

Mills NT, Scott JG, Wray NR, Cohen-Woods S, Baune BT (2013) Research review: the role of cytokines in depression in adolescents: a systematic review. J Child Psychol Psychiatry 54: 816-815

Moylan S, Berk M, Dean OM, Samuni Y, Williams LJ (2014) Oxidative \& nitrosative stress in depression: why so much stress? Neurosci Biobehav Rev 45: 46-62. http://doi.org/10.1016/j.neubiorev.2014.05.007

Moylan S, Maes M, Wray NR, Berk M (2013) The neuroprogressive nature of major depressive disorder: pathways to disease evolution and resistance, and therapeutic implications. Mol Psychiatry 18: 595606. http://doi.org/10.1038/mp.2012.33

Naude PJ, Dobos N, van der Meer D, Mulder C, Pawironadi KG, den Boer JA, van der Zee EA, Luiten PG, Eisel UL (2014) Analysis of cognition, motor performance and anxiety in young and aged tumor necrosis factor alpha receptor 1 and 2 deficient mice. Behav Brain Res 258: 43-51. http://doi.org/10.1016/j.bbr.2013.10.006

O'Brien SM, Scully P, Fitzgerald P, Scott LV, Dinan TG (2007) Plasma cytokine profiles in depressed patients who fail to respond to selective serotonin reuptake inhibitor therapy. I Psychiatric Res 41: 326-331. http://doi.org/10.1016/j.jpsychires.2006.05.013

O'Donovan A, Rush G, Hoatam G, Hughes BM, McCrohan A, Kelleher C, O'Farrelly C, Malone KM (2013) Suicidal ideation is associated with elevated inflammation in patients with major depressive disorder. Depress Anxiety 30: 307-314. http://doi.org/10.1002/da.22087

Oliveira Miranda D, Soares de Lima TA, Ribeiro Azevedo L, Feres O, Ribeiro da Rocha JJ, Pereira-da-Silva G (2014) Proinflammatory cytokines correlate with depression and anxiety in colorectal cancer patients. Biomed Res Int 2014: 739650. http://doi. org/10.1155/2014/739650

Pandey GN, Rizavi HS, Ren X, Fareed J, Hoppensteadt DA, Roberts RC, Conley RR, Dwivedi Y (2012) Proinflammatory cytokines in the prefrontal cortex of teenage suicide victims. I Psychiatr Res 46: 57-63. http://doi.org/10.1016/j.jpsychires.2011.08.006

Park M, Newman LE, Gold PW, Luckenbaugh DA, Yuan P, Machado-Vieira R, Zarate CA Jr (2016) Change in cytokine levels is not associated with rapid antidepressant response to ketamine in treatment-resistant depression. J Psychiatr Res 84: 113-118. http://doi. org/10.1016/j.jpsychires.2016.09.025

Patten S (1997) Performance of the Composite International Diagnostic Interview Short Form for major depression in community and clinical samples. Chron Dis Can 3: 18-24.

Pickering M, O'Connor JJ (2007) Pro-inflammatory cytokines and their effects in the dentate gyrus. Prog BrainRes 163: 339-354. http://doi. org/10.1016/S0079-6123(07)63020-9

Raison CL, Rutherford RE, Woolwine BJ, Shuo C, Schettler P, Drake DF, Haroon E, Miller AH (2013) A randomized controlled trial of the tumor necrosis factor antagonist infliximab for treatment-resistant depression: the role of baseline inflammatory biomarkers. $A r$ chives of General Psychiatry 70: 31-41. http://doi.org/10.1001/2013. jamapsychiatry.4

Schmidt FM, Lichtblau N, Minkwitz J, Chittka T, Thormann J, Kirkby KC, Sander C, Mergl R, Faßhauer M, Stumvoll M, Holdt LM, Teupser D, Hegerl U, Himmerich H (2014) Cytokine levels in depressed and non-depressed subjects, and masking effects of obesity. J Psychiatr Res. 55: 29-34. http://doi.org/10.1016/j.jpsychires.2014.04.021

Schuld A, Schmid DA, Haack M, Holsboer F, Friess E, Pollmächer T (2003) Hypothalamo-pituitary-adrenal function in patients with depressive disorders is correlated with baseline cytokine levels, but not with cytokine responses to hydrocortisone. J. Psychiatr Res 37: 463-70. 
Serafini G, Pompili M, Elena Seretti M, Stefani H, Palermo M, Coryell W, Girardi P (2013) The role of inflammatory cytokines in suicidal behavior: a systematic review. Eur Neuropsychopharmacol 23: 16721686. http://doi.org/10.1016/j.euroneuro.2013.06.002

Silverman MN, Pearce BD, Biron CA, Miller AH (2005) Immune modulation of the hypothalamic-pituitary-adrenal (HPA) axis during viral infection. Viral Immunol 18: 41-78. http://doi.org/10.1089/ vim.2005.18.41

Simpson W, Steiner M, Coote M, Frey BN (2016) Relationship between inflammatory biomarkers and depressive symptoms during late pregnancy and the early postpartum period: a longitudinal study. Rev Bras Psiquiatr 38: 190-196. http://doi.org/10.1590/15164446-2015-1899

Singhal G, Jaehne EJ, Corrigan F, Toben C, Baune BT (2014) Inflammasomes in neuroinflammation and changes in brain function: a focused review. Front Neurosci 8: 315. http://doi.org/10.3389/ fnins.2014.00315

Smagula SF, Lotrich FE, Aizenstein HJ, Diniz BS2, Krystek J, Wu GF, Mulsant BH, Butters MA, Reynolds CF 3rd, Lenze EJ (2016) Immunological biomarkers associated with brain structure and executive function in late-life depression: exploratory pilot study. Int J Geriatr Psychiatry. 2016 Jun 10. doi: 10.1002/gps.4512. [Epub ahead of print] http://doi.org/10.1002/gps.4512

Stellwagen D, Malenka RC (2016) Synaptic scaling mediated by glial TNF- $\alpha$. Nature 440: 1054-1059. http://doi.org/10.1038/nature04671

Sudheimer KD, O'Hara R, Spiegel D, Powers B, Kraemer HC, Neri E, Weiner M, Hardan A, Hallmayer J, Dhabhar FS (2014) Cortisol, cytokines, and hippocampal volume interactions in the elderly. Front Aging Neurosci 6: 153. http://doi.org/10.3389/fnagi.2014.00153
Szczepanska-Sadowska E, Cudnoch-Jedrzejewska A, Ufnal M, Zera T (2010) Brain and cardiovascular diseases: common neurogenic background of cardiovascular, metabolic and inflammatory diseases. J Physiol Pharmacol 61: 509-521.

Talarowska M, Bobińska K, Zajączkowska M, Su KP, Maes M, Gałecki $P$ (2014) Impact of oxidative/nitrosative stress and inflammation on cognitive functions in patients with recurrent depressive disorders. Med Sci Monit 20: 110-115. http://doi.org/10.12659/MSM.889853

Talarowska M, Gałecki P, Maes M, Bobińska K, Kowalczyk E (2012) Total antioxidant status correlates with cognitive impairment in patients with recurrent depressive disorder. Neurochemical Research 37: 1761-1767. http://doi.org/10.1007/s11064-012-0788-z

Talarowska M, Szemraj J, Zajączkowska M, Gałecki P (2014b) ASMT gene expression correlates with cognitive impairment in patients with recurrent depressive disorder. Med Sci Monit 20: 905-912. http://doi.org/10.12659/MSM.890160

Talarowska M, Zboralski K, Gałecki P (2013) Correlations between working memory effectiveness and depression levels after pharmacological therapy. Psychiatr Pol 47: 255-267.

Winer J, Jung CK, Shackel I, Williams PM (1999) Development and validation of real-time quantitative reverse transcriptase-polymerase chain reaction for monitoring gene expression in cardiac myocytes in vitro. Anal Biochem 270: 41-49. http://doi.org/10.1006/ abio. 1999.4085

Young JJ, Bruno D, Pomara N (2014) A review of the relationship between proinflammatory cytokines and major depressive disorder. J Affect Disord 169: 15-20. http://doi.org/10.1016/j.jad.2014.07.032 